\title{
Magnesium in crop production, food quality and human health
}

\author{
Ismail Cakmak
}

Received: 14 May 2013 / Accepted: 17 May 2013 /Published online: 1 June 2013

(C) Springer Science+Business Media Dordrecht 2013

Magnesium $(\mathrm{Mg})$ has diverse physiological functions in biological systems. Among the essential mineral nutrients required by plants, $\mathrm{Mg}$ has important roles in phloem loading and transport of photoassimilates into sink organs such as roots, shoot tips and seeds (Cakmak et al. 1994a; Hermans et al. 2005). Magnesium is also a mineral nutrient with highly positive impacts on photosynthesis, enzyme activation, and formation and utilization of ATP. It is therefore not surprising that the growth of plants, especially sink organs (e.g., root and seed formation), is significantly affected by a low supply of $\mathrm{Mg}$ in soil (Hermans et al. 2005; Cakmak and Kirkby 2008). Similarly, adequate $\mathrm{Mg}$ nutrition is also of particular importance for grazing animals, since a low Mg supply in soils may induce grass tetany, a potentially fatal metabolic disorder in animals (Grunes and Welch 1989). In view of its particular protective roles against cardiovascular diseases, strokes and diabetes (Bo and Pisu 2008), $\mathrm{Mg}$ concentration in food crops and daily diet is also becoming an important world-wide issue in food quality and human nutrition (Broadley and White 2010).

The concerns associated with low Mg levels in soil, feed and food were addressed by the selected keynote

Responsible Editor: Hans Lambers.

I. Cakmak ( $\bowtie)$

Faculty of Engineering and Natural Sciences,

Sabanc1 University, 34956 Istanbul, Turkey

e-mail: cakmak@sabanciuniv.edu speakers at the First International Magnesium Symposium held at the Georg-August-University Göttingen in Germany between 8 and 9 May, 2012, with more than 125 participants from 30 countries. The symposium was hosted by the Institute of Applied Plant Nutrition (IAPN) at the Göttingen University and jointly organized with the Sabanci University, Istanbul, Turkey and the Center for Magnesium Education and Research, Hawaii, USA.

This paper summarizes the main findings and key messages of this symposium. One of the key topics addressed at the symposium focused on different binding forms, solubility and root uptake of $\mathrm{Mg}$ in soil. Special attention is given to the relationship between soil $\mathrm{Mg}$ deficiency (Mg saturation) and plant growth under environmental stress conditions, especially drought stress and soil acidity. The importance of balanced crop $\mathrm{Mg}$ nutrition is also highlighted as a fundamental issue in intensive crop production due to rapid depletion of $\mathrm{Mg}$ from the soil profile. Of particular interest and discussion was the question of how and why adequate $\mathrm{Mg}$ nutrition is required for better crop yields under adverse soil and climatic conditions, such as heat and water scarcity. Results presented at the symposium and published in this issue provide better understanding and interpretation of the stressmitigating impacts of adequate $\mathrm{Mg}$ nutrition in crop plants. Presence of sufficient soluble $\mathrm{Mg}$ in soil is also needed to avoid $\mathrm{Mg}$ deficiency risk ("grass tetany") and to improve productivity of grazing animals. Grass tetany, representing a serious disorder in ruminants, is 
also induced by heavy application of $\mathrm{K}$ fertilizers into soil. Therefore, besides $\mathrm{Mg}$ concentrations, attention should be also paid to $\mathrm{K} / \mathrm{Mg}$ ratio in leaf tissue of grasses grown in the regions where grass tetany is a potential risk.

Adequate $\mathrm{Mg}$ nutrition of crop plants is important for better nitrogen- $(\mathrm{N})$ use efficiency and grain $\mathrm{N}$ accumulation. It appears that $\mathrm{Mg}$ has positive effects on $\mathrm{N}$-uptake efficiency of plants. A number of key physiological processes in plant cells which are adversely affected by low soil Mg supply are here presented and discussed. Very early and severe impairments in the growth and development of sink organs such as youngest shoot parts and roots under $\mathrm{Mg}$ deficiency (Fig. 1) has been ascribed to impaired phloem export of photoassimilates from the source organs (e.g., from the fully expanded leaves). In many cases, $\mathrm{Mg}$ deficiency stress markedly increases shoot to root dry weight ratio. Similarly, K deficiency can also result in increases in shoot to root dry weight ratio as shown in common bean plants and silver birch seedlings (Cakmak et al. 1994b; McDonald et al. 1996; Fig. 2). Like Mg, K also has an important role in phloem loading and transport of carbohydrates in plants (Mengel and Haeder 1977; Cakmak et al. 1994b). It has been reported that the initial effects of $\mathrm{Mg}$ deficiency occur in the youngest shoot parts, especially in case of exposure of Mg-adequate plants to Mg-deficient conditions (Hermans et al. 2004). The effects of $\mathrm{Mg}$ and $\mathrm{K}$

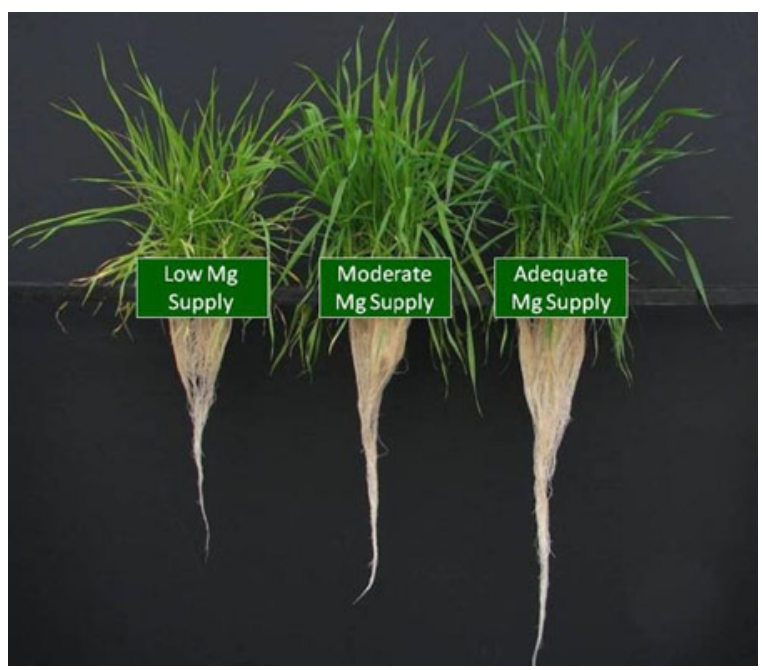

Fig. 1 Root and shoot growth of wheat plants grown in a nutrient solution with very low $(10 \mu \mathrm{M} \mathrm{Mg})$, moderate $(25 \mu \mathrm{M} \mathrm{Mg})$ and adequate $(500 \mu \mathrm{M} \mathrm{Mg})$ magnesium supply for 38 days



Fig. 2 Changes in root to shoot dry weight ratio in silver birch (Betula pendula) seedlings depending on the differential supply of nitrogen $(\mathrm{N}), \mathrm{P}$ (phosphorus $\mathrm{P}$ potassium $(\mathrm{K})$ and $\mathrm{Mg}$. The relative nutrient supply 100 indicates optimum supply of those nutrients (Mcdonald et al. 1996)

deficiencies on shoot to root dry weight ratio seems to be very specific. In contrast to $\mathrm{K}$ or $\mathrm{Mg}$ deficiency, phosphorus $(\mathrm{P})$ or $\mathrm{N}$ deficiencies lead to greater allocation of biomass into roots, resulting in greater shoot to root dry weight ratios, probably as an adaptive root response of plants to $\mathrm{P}$ and $\mathrm{N}$ deficiencies (McDonald et al. 1996; Fig. 2).

One of the important experimental results presented at the symposium was the protective role of $\mathrm{Mg}$ against heat and excess light stress in plants (Fig. 3). As shown in Fig. 3, expression of Mg deficiency-induced leaf chlorosis in common bean plants was markedly prevented or promoted by a partial shading or partial exposure to high light of Mg-deficient leaves, respectively. Wheat and corn plants were also highly susceptible to heat stress when grown under low $\mathrm{Mg}$ supply. It was concluded that ensuring a sufficiently high $\mathrm{Mg}$ supply for crop plants through $\mathrm{Mg}$ fertilization is an important requirement for minimizing heat- and radiation-related losses in crop production.

Another impressive impact of adequate Mg supply is related to its mitigating effect on aluminum (Al) toxicity in plants which is a common growth-limiting constraint in acidic soils globally. The mechanisms behind the protective effects of $\mathrm{Mg}$ on $\mathrm{Al}$ toxicity are not yet fully understood. Most probably, mechanisms including exudation of organic acid anions, better carbon partitioning from shoots to roots, maintenance of $\mathrm{H}^{+}$-ATPase 
Fig. 3 Development of leaf chlorosis in magnesiumdeficient common bean plants. Leaves studied were partially shaded (light intensity on shaded areas: about $100 \mu \mathrm{mol}$ photons $\mathrm{m}^{-2} \mathrm{~s}^{-1}$ ) or exposed to high light intensity (light intensity on the light exposed-areas: about $500 \mu \mathrm{mol}$ photons $\mathrm{m}^{-2} \mathrm{~s}^{-1}$ ) for 7 days

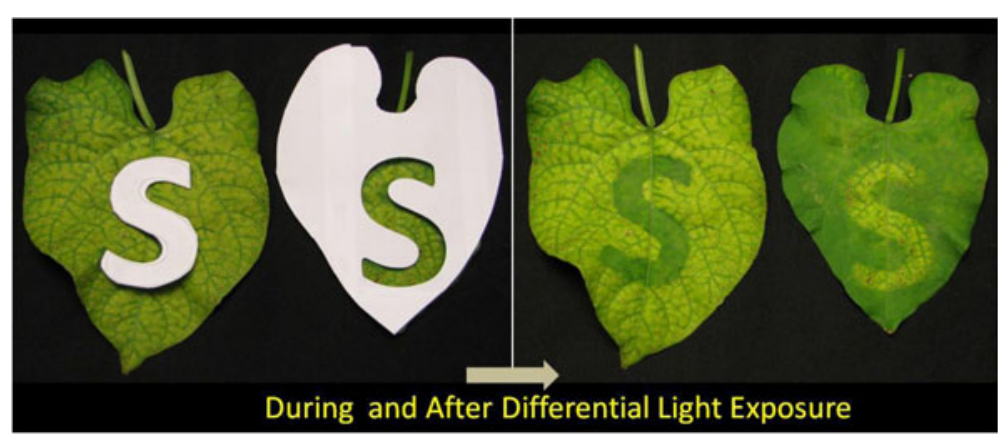

activity on plasma membranes and better cytoplasmic $\mathrm{pH}$ regulation are involved in the protective actions of $\mathrm{Mg}$ in plants exposed to $\mathrm{Al}$ toxic soil conditions. In case of Al-resistant rice plants, two genes have been identified in roots whose expression is induced upon exposure of roots to Al. It seems that these genes are positive regulators of $\mathrm{Mg}$ transporters. Magnesium nutrition has also been discussed regarding its influence on expression of plant resistance to diseases. Depending on the pathogen/pest, plant species and environmental conditions, $\mathrm{Mg}$ nutrition may increase or decrease disease incidence. Well-known increases in susceptibility of plants to diseases under very high K supply were associated with low tissue concentrations of $\mathrm{Mg}$ and calcium $(\mathrm{Ca})$. High accumulation of sugars in source leaves under $\mathrm{Mg}$ deficiency due to impaired phloem transportation may promote pathogen invasion and infection.

Molecular genetic responses of plants to low $\mathrm{Mg}$ supply was also discussed in the Mg symposium. A global transcriptomic analysis following very early (within hours) and late (within days but before development of visual symptoms) $\mathrm{Mg}$ starvation treatment was reported. Major responses observed include the perturbation of the central oscillator of the circadian clock and the triggering of the ABA and ethylene signalosome. Magnesium was found to be involved as sensory input of the plant circadian clock. Upon Mg depletion, an alteration in expression of transcription factors related to the circadian clock was found, and this alteration happened before sugar accumulation in source leaves took place.

Several examples show how quality parameters (e.g. chemical composition) of various sugar, tuber and oil crops are affected by varied $\mathrm{Mg}$ supply. Generally, a greater impact of $\mathrm{Mg}$ on quality parameters was found when $\mathrm{Mg}$ was supplied to low-Mg plants. But, there were no additional benefits when $\mathrm{Mg}$ was applied to plants already grown under adequate $\mathrm{Mg}$ supply conditions. However, any increase in $\mathrm{Mg}$ concentration in edible parts of food crops following soil or foliar applications of $\mathrm{Mg}$ fertilizers may have important impact on human and livestock nutrition.

Excess dietary sodium $(\mathrm{Na})$ intakes, at a level much higher than required, are becoming a growing nutritional problem in human populations, especially in welldeveloped countries due to high consumption of highly processed, packet and canned foods and meat products. Scientists and food industry are looking for strategies to reduce dietary $\mathrm{Na}$ intake. At the $\mathrm{Mg}$ symposium, a complete or partial substitution of $\mathrm{Na}$ with $\mathrm{Mg}$ in the diet was suggested as a possible solution to this growing $\mathrm{Na}$ concern. Results presented indicated that $\mathrm{Mg}$ with its number of positive impacts on human health represents a good candidate mineral to develop low-sodium food products while providing high $\mathrm{Mg}$ content that may also contribute to better counterbalancing the adverse effects of excess $\mathrm{Na}$ ions in body.

Dietary Mg supply was shown to vary considerably among countries. Extensive amount of valuable food composition tables and food balance sheets were used to show that dietary daily $\mathrm{Mg}$ supply per capita in Africa shows a substantial variation among the countries, ranging from $188 \mathrm{mg} \mathrm{d}^{-1}$ in Eritrea to $1828 \mathrm{mg} \mathrm{d}^{-1}$ in Burkina Faso. It seems that cereals are the major source of the daily intake of $\mathrm{Mg}$ (up to $75 \%$ in some regions). Based on the available results, dietary $\mathrm{Mg}$ deficiency in Africa is unlikely to be a major problem. In contrast to the results in Africa, there are greater dietary $\mathrm{Mg}$ deficiency risks in many western countries like in USA and UK. Reports presented at the symposium indicate increasing Mg- deficiency risk in humans in well-developed countries. Besides low $\mathrm{Mg}$ concentrations in the body, very high daily $\mathrm{Ca}$ intake induces high $\mathrm{Ca}: \mathrm{Mg}$ intracellular ratios, which then potentiate cellular Mg deficiency. Analysis of historical grain samples indicates an important decline in concentrations of $\mathrm{Mg}$ in cereal grains over the past several decades, most likely due to yield dilution effects. In 
addition, there is a significant amount of $\mathrm{Mg}$ loss in food processing. Increasing $\mathrm{Mg}$ concentrations in edible parts of plants is, therefore, believed to be an important strategy in reducing $\mathrm{Mg}$ deficiency in human beings. Magnesium is known to be protective against several diseases, including cardiovascular diseases, which commonly occur in patients having Mg deficiency. Reports indicate positive impacts of $\mathrm{Mg}$ therapy against myocardial infarction. Magnesium deficiency is also associated with the pathogenesis of diabetes mellitus.

This Mg symposium was the first international symposium on $\mathrm{Mg}$ focusing predominantly on impacts of $\mathrm{Mg}$ on crop production and nutritional quality. In contrast to many other mineral nutrients, there is not yet any regular series of Mg symposiums/meetings in plant biology. At the Symposium in Göttingen, it was decided to organize a "Second International Magnesium Symposium" in Brazil in 2014. The organizers thank $\mathrm{K}+\mathrm{S}$ Kali $\mathrm{GmbH}$ for its great support, and Plant and Soil for devoting a part of this issue to the selected papers from this Magnesium Symposium.

\section{References}

Bo S, Pisu E (2008) Role of dietary magnesium in cardiovascular diseases prevention, insulin sensitivity and diabetes. Curr Opin Lipid 19:50-56
Broadley MR, White PJ (2010) Eats roots and leaves. Can edible horticultural crops address calcium, magnesium and potassium deficiencies? Proc Nutr Soc 69:601-612

Cakmak I, Kirkby EA (2008) Role of magnesium in carbon partitioning and alleviating photooxidative damage. Physiol Plant 133:692-704. doi:10.1111/j.1399-3054.2007.01042.x

Cakmak I, Hengeler C, Marschner H (1994a) Changes in phloem export of sucrose in leaves in response to phosphorus, potassium and magnesium deficiency in bean plants. J Exp Bot 45:1251-1257. doi:10.1093/jxb/45.9.1251

Cakmak I, Hengeler C, Marschner H (1994b) Partitioning of shoot and root dry matter and carbohydrates in bean plants suffering from phosphorus, potassium and magnesium deficiency. J Exp Bot 45:1245-1250. doi:10.1093/jxb/45.9.1245

Grunes DL, Welch RM (1989) Plant contents of magnesium, calcium and potassium in relation to ruminant nutrition. $\mathrm{J}$ Anim Sci 67:3485-3494

Hermans C, Johnson GN, Strasser RJ, Verbruggen N (2004) Physiological characterization of magnesium deficiency in sugar beet: acclimation to low magnesium differentially affects photosystems I and II. Planta 220:344-355. doi:10.1007/s00425-004-1340-4

Hermans C, Bourgis F, Faucher M, Strasser RJ, Delrot S, Verbruggen N (2005) Magnesium deficiency in sugar beets alters sugar partitioning and phloem loading in young mature leaves. Planta 220:541-549. doi:10.1007/s00425004-1376-5

McDonald AJ, Ericsson T, Larsson CM (1996) Plant nutrition, dry matter gain and partitioning at the whole-plant level. J Exp Bot 47:1245-1253

Mengel K, Haeder HE (1977) Effect of potassium supply on the rate of phloem sap exudation and the composition of phloem sap of Rizinus communis. Plant Physiol 59:282-284 